\title{
The Edaphic Factor in the Origin of Plant Species
}

\author{
NISHANTA RAJAKARUNA ${ }^{1}$ \\ Department of Biological Sciences, Stanford University, Stanford, California 94305-5020
}

\begin{abstract}
Although speciation has been a central focus in evolutionary biology for more than a century, there are very few case studies where we have a good understanding of the exact forces that may have acted in the diversification of a group of organisms. In order to examine such forces, botanists have often focused on closely related plants that are found under contrasting soil conditions. The study of such edaphically differentiated plants has provided valuable insight to the role of natural selection in evolution. This paper discusses several key studies that have appeared in the literature in the last half century emphasizing the role unusual soil conditions-such as those found on serpentinite outcrops, mine tailings, guano deposits, and salt flats—can play in the diversification of plant species. Many of these studies have not only shown adaptive differentiation in response to various edaphic features, but have also attempted to examine the link between adaptive traits and traits that are directly responsible for reproductive isolation between the divergent taxa. With the advent of novel genetic techniques and an increased understanding of the genetic architecture of various adaptive traits dealing with substrate tolerance, it will soon be possible to demonstrate the central role of the edaphic factor in plant evolution.
\end{abstract}

\section{Introduction}

The red-rock forest may seem hellish to us, but it is a refuge to its flora.... it is the obdurate physical (and chemical) adversity of things such as peridotite (ultramafic) bedrock which often drives life to its most surprising transformations.

\section{—D. R. Wallace (1983)}

Plants With UNUSUal or localized distribution patterns have always fascinated botanists and other natural historians. The study of such plants has provided information on the history and evolution of certain regions and their floras. Further, these plants have provided opportunities to investigate aspects of evolutionary ecology and population dynamics unique to such plant populations (Liu and Godt, 1983; Linhart and Grant, 1996).

Climate sets the limits for biota; however, geology enriches discontinuity and habitat diversity (Jenny, 1941). The classic generalizations on the distribution of plants (Cain, 1944) place the edaphic factor second only to climate as the major environmental determinants of plant distribution. The edaphic factor pertains to the substratum upon which the plant grows and from which it derives its

${ }^{1}$ Email: nishanta@stanford.edu mineral nutrients and much of its water supply. It involves physical, chemical, and biological properties of soils (Mason, 1946a, 1946b). When physical and chemical properties of substrate are arrayed discontinuously, opportunities for colonization by different species as well as events leading to speciation can occur (Kruckeberg, 1986).

Edaphic islands such as serpentinite and limestone outcrops, guano deposits, and mine tailings give rise to localized patterns of plant distributions, and provide a model setting to study the role of the edaphic factor in plant evolution. Closely related taxa in many cases are distinguished by their distinct edaphic tolerances (Macnair and Gardner, 1998; Rajakaruna and Whitton, 2004). Populations of certain taxa may have the genetic preadaptedness to venture successfully onto soils that are edaphically extreme: a few preadapted genotypes could become founders of a tolerant population. Genetic accommodation to extreme edaphic conditions can take place quite rapidly and, in the case of heavy metals, even within a few generations (Antonovics et al., 1971; Bradshaw and McNeilly, 1981; Shaw, 1990; Al-Hiyali et al., 1993). Hence, edaphic conditions, when manifested in extreme form, can be potent agents of natural selection.

Several modes of origin of edaphically specialized taxa have been proposed: biotype depletion, drift, catastrophic selection and saltational specia- 
tion, standard allopatric speciation with ecogeographic specialization, ecotypic differentiation, and hybridization with or without allopolyploidy are some modes of origin presented to explain edaphic specialization or endemism (Stebbins, 1942, 1980; Stebbins and Major, 1965; Proctor and Woodell, 1975; Raven and Axelrod, 1978; Kruckeberg, 1984, 1986; Kruckeberg and Rabinowitz, 1985). Using serpentinite soils as an example of a challenging edaphic situation, Kruckeberg (1984, 1986) described a set of stages that may lead to the establishment of an edaphically endemic species. Firstly, there exists preadaptedness for serpentinite tolerance in nonserpentinite populations. Then, disruptive selection, catastrophic selection (Lewis, 1962; Raven, 1964), or gradual divergence effectively separates the species into serpentinite-tolerant and -intolerant gene pools. Further genetic divergence in structural and functional traits occurs within the serpentinite-tolerant part of the effectively discontinuous populations. As a result, isolation between serpentinite-tolerant and -intolerant populations becomes fixed, and the two populations are unable to exchange genes. Further divergence of the serpentinite ecotype leads to an edaphically endemic species. This sequence encompasses an evolutionary history from the initial tolerance of the habitat by certain preadapted variants to clear-cut species formation. These stages can be appropriately applied to other forms of geoedaphic challenges-mine soils with heavy metals (Antonovics et al., 1971; Bradshaw et al., 1990), guano (Gillham, 1956; Ornduff, 1965; Vasey, 1985), vernal pools (Holland and Jain, 1977, 1981), granite outcrops (Wyatt and Fowler, 1977; Ornduff, 1986), salt marshes (Flowers et al., 1986), gypsum (Turner, 1973; Turner and Powell, 1979), dolomite (Mooney, 1966; Lloyd and Mitchell, 1973), and limestone (Baskin and Baskin, 1988; Quarterman et al., 1993) — also leading to the formation of edaphically endemic taxa.

While the stages illustrated by Kruckeberg (1986) may represent more or less an accurate description of the steps through which evolution proceeds from tolerant genotype to ecotype to an edaphic endemic, it does not indicate why some genotypes evolve through all the steps and others do not. The crucial step differentiating an ecotype from an endemic is likely to be the acquisition of complete reduction in gene flow between the ancestral population and ecotype, allowing an independent gene pool to develop (Macnair and Gardner, 1998).
How this occurs, in the absence of an extrinsic barrier to gene flow between two contiguous populations (i.e., races, ecotypes) is a fundamental question in speciation research.

\section{Case Studies of Endemism}

Several important studies from 1960 to the present have focused attention on the role of edaphic factors in the process of plant speciation. These studies not only characterize adaptations to unusual soil conditions but also demonstrate a direct or indirect effect of those particular adaptations on reproductive isolation. These include the series of classic papers by Bradshaw and colleagues entitled "Evolution in closely adjacent plant populations" (McNeilly, 1968; McNeilly and Antonovics, 1968; McNeilly and Bradshaw, 1968; Antonovics and Bradshaw, 1970). Their work is perhaps the most-cited series of studies showing the power of natural selection driven by edaphic features in the process of plant speciation.

In their work on two grass species growing on and off mine tailings in Europe, Bradshaw and colleagues were able to demonstrate that the metaltolerant and -intolerant individuals of these grasses are better adapted to their distinct microedaphic habitats and are also reproductively isolated. Their work suggests that prezygotic isolating mechanisms, both flowering-time differences and a shift toward increased selfing, are primarily responsible for the isolation observed between the edaphically divergent populations. Flowering time differences are simple yet effective means of isolating populations (Antonovics, 1968; Stam, 1983). However, whether flowering-time differences arise as a direct effect of selection for reduced gene flow to avoid maladaptive hybridization (i.e., reinforcement) or as a by-product of a physiological adaptation to distinct soil conditions, specifically drought, are often debated (Macnair and Baker, 1994). In the case of these grasses, McNeilly and Antonovics (1968) implied reinforcement for the observed differences, but suggest that part of the isolation may arise from temperature differences in the microedaphic habitats of the distinct populations. In addition, Antonovics (1968) showed that isolation has also come about by a shift toward increased selfing in the metal-tolerant populations, further reducing opportunities for gene exchange between metal-tolerant and -intolerant individuals.

The next two case studies that show the role of edaphic factors in speciation come from the sun- 
flower family (Asteraceae). The genus Lasthenia is endemic to the Californian Floristic Province and consists of several edaphically restricted taxa (Rajakaruna, 2003). The first example deals with the closely related species pair consisting of L. minor and L. maritima. Lasthenia minor (DC.) Ornduff occurs in a variety of habitats such as alkali flats, coastal bluffs, sand dunes, pond margins, and disturbed sites, whereas L. maritima (A. Gray) M. Vasey is restricted almost exclusively to islands and offshore rocks harboring seabird nesting and roosting sites (Ornduff, 1965, 1966; Vasey, 1985). The soils on these sites are high in nitrogen, low in $\mathrm{pH}$, and highly disturbed from the activities of the birds (Vasey, 1985). In addition, exposure to constant wind and salt spray makes guano deposits an outright hostile environment. Preliminary studies by Vasey (1985) showed that $L$. minor is not tolerant of guano-modified soils.

Ornduff (1966) considered the self-compatible L. maritima to be a recent descendent from the selfincompatible L. minor. An electrophoretic study (Crawford et al., 1985) further supported this hypothesis, and suggested that speciation probably involved a switch to self-compatibility, development of autogamy (i.e., the process of self-fertilization), and subsequent divergence driven by edaphic factors. Given that variation for tolerance is first required to colonize the extreme guano habitats, it is likely that self-compatibility arose post-colonization, and that the origin of L. maritima represents another classic example of an edaphically driven event of speciation. Whether the switch to self-compatibility arose as a by-product of an adaptation to guano or is directly linked to genes conferring adaptation is not known.

A recent phylogenetic study (Chan et al., 2001) shows a close relationship between the two species, but does not conclusively support Ornduff's (1966) and Crawford et al.'s (1985) proposed ancestordescendent relationship. Nevertheless, the close relationship between the two species is reflected by the high fertility of artificial crosses (Ornduff, 1966). However, Vasey (1985) reported that at the only truly sympatric site known for the two species, only a few plants appear to be intermediates. Examination of parapatric populations of the two species at three localities failed to reveal any indication of natural interspecific hybridization (Vasey, 1985) suggesting that strong ecological selection is likely responsible for limiting introgression. Here is an example of not only prezygotic barriers (i.e., increased selfing) leading to isolation of edaphically divergent taxa, but also possible post-zygotic barriers (i.e., reduced hybrid fitness in the parental habitats) allowing the ecological divergence of these two taxa.

The physiological basis for the substrate tolerance in L. maritima is not known. Current work (Rajakaruna, Okamoto, and Vasey, in progress) is directed toward assessing mechanisms of tolerance to guano soils. Once trait differences are established between the two species and their adaptive significance determined, it will be possible to examine their genetic basis. Whether traits contributing to adaptation to guano soils also contribute to isolation (i.e., self-compatibility or reduced hybrid fitness) can then be examined.

Lasthenia californica sensu Ornduff (Asteraceae), the common goldfields of California, is another species complex that is ideally suited for the study of various factors and mechanisms that are involved in the process of speciation driven by edaphic forces (Rajakaruna, 2003). A recent molecular phylogenetic study documented that $L$. californica sensu Ornduff consists of two cryptic species, L. californica subsp. californica DC. ex Lindl. and L. gracilis (DC) Greene (Chan et al., 2001, 2002). Previous research had shown that there are two edaphic races within this complex, with one race (A) occupying ionically extreme soils such as serpentinite outcrops, coastal bluffs, alkaline flats, and the other $(\mathrm{C})$, occupying ionically moderate yet waterstressed soils (Rajakaruna and Bohm, 1999). Genetic studies have confirmed that the two races are found in both species of the complex, and that race $C$ has evolved multiple times from race $A$ (Rajakaruna and Whitton, 1994; Rajakaruna et al., 2003a). Greenhouse studies showed that both races are physiologically differentiated and perform better under conditions that match their native habitats.

Race A has a 20-fold higher sodium ion uptake rate, as well as a twofold higher uptake rate for both calcium and magnesium, ions that predominate in their habitats. Measures of germination, survivorship, and root length also suggested that tolerance to ionic stresses by race A plants is not based upon ion exclusion, pointing to internal mechanisms of tolerance (Rajakaruna et al., 2003c). In contrast, race C is better adapted to drought, and avoids drought by faster growth to reproductive maturity and by allocating relatively more biomass to reproduction (Rajakaruna et al., 2003b). Crossing studies showed that reproductive isolation via pollen 
incompatibility is stronger between populations of the two races than between populations of the same race, even though race $\mathrm{C}$ populations have had distinct origins (Rajakaruna and Whitton, 2004). Furthermore, in the only known parapatric location of the two edaphic races (serpentine outcrop at Jasper Ridge Biological Preserve, San Francisco Peninsula, California), flowering times between the races differ by 7-10 days, providing an effective barrier to reproduction (Rajakaruna and Bohm, 1999). These findings suggest that traits bringing about reproductive isolation may have accompanied adaptive traits that are likely involved in the ecological divergence.

Although it is possible that both enhanced pollen incompatibility and the flowering time differences are both under direct ecological selection (Searcy and Macnair, 1990; McNeilly and Antonovics, 1968), it is more likely that these prezygotic barriers have come about as by-products of divergence under ecological selection (Rajakaruna and Whitton, unpubl. manuscript). The system is unique in that it is one of the better documented cases to date of parallel speciation under the edaphic influence-i.e., the parallel evolution of both adaptive traits and traits that bring about reproductive isolation in edaphically divergent populations belonging to closely related species. Future research will be directed at determining the genetic basis for traits that are involved in adaptation (salt tolerance, drought tolerance) and reproductive isolation (flowering time differences) in order to better understand the relationship between adaptation to substrate and diversification in this group.

The final and perhaps the best-studied example involving the role of the edaphic factor in divergence comes from the long-term studies by Macnair and colleagues at the University of Exeter, United Kingdom (Macnair and Christie, 1983; Christie and Macnair, 1987; Macnair et al., 1989; Macnair and Gardner, 1998; Gardner and Macnair, 2000) on the Mimulus guttatus complex (Phrymaceae). Their work clearly suggests that reproductive isolation can be achieved as a by-product of a physiological adaptation to unusual soil conditions. Mimulus guttatus DC (seep monkeyflower) is a widespread and highly polymorphic species found throughout western North America (Vickery, 1959, 1978; Allen and Sheppard, 1971). Mimulus guttatus is the probable progenitor of a number of taxa that are restricted to unusual soil conditions: M. nudatus E. Greene and M. pardalis Pennel are serpentinite endemics, whereas M. cupriphilus Macnair and an ecotype of M. guttatus are restricted to copper-rich mine tailings (Macnair and Gardner, 1998). All four edaphically specialized taxa flower prior to normal populations of $M$. guttatus, providing a potent barrier to reproduction. Secondly, there are pollinator differences between the presumed progenitor and the edaphically restricted taxa, resulting primarily from differences in flower size (Gardner and Macnair, 2000). Thirdly, while $M$. guttatus is an outcrosser, both M. pardalis (serpentinite endemic) and M. cupriphilus (copper mine endemic) are self-compatible, again reducing opportunities for gene flow between the progenitor and the derived species. Searcy and Macnair (1990) have also shown pollen incompatibility reactions between the copper tolerant and intolerant individuals of $M$. guttatus, similar to the case in the L. californica complex. However, they provide evidence to suggest that the concentration of copper in the pistil can contribute toward the level of isolation observed. This would mean that edaphic conditions, specifically the level of copper that is available for plant uptake and translocation to the pistil, may have a more direct effect on reproductive isolation between these distinct individuals than previously thought.

Although all these mechanisms can provide effective prezygotic barriers against gene flow, Macnair and colleagues have elegantly demonstrated that a potent post-zygotic barrier to reproduction also exists between the normal $M$. guttatus individuals and the copper-tolerant individuals of this species (Macnair and Christie, 1983). They have shown that the linkage block associated with copper tolerance in the ecotype also produces hybrid inviability; however, it is unclear if inviability is achieved via pleiotropy or hitchhiking. Subsequent work by this group (Christie and Macnair 1984, 1987) and previous work by Vickery (1978) have shown that both copper tolerance and hybrid inviability genes are commonly segregating in normal populations of this species, suggesting that hitchhiking is probable. Nevertheless, this work has clearly documented that natural selection for a clearly adaptive trait (copper tolerance) has caused a gene for post-zygotic isolation to spread through the population (Macnair and Christie, 1983; Christie and Macnair, 1987), providing strong evidence for the direct relationship between adaptation to substrate and reproductive isolation, i.e., the direct role of the edaphic factor in plant evolution. 


\section{Discussion}

Although the case studies above provide evidence for mostly prezygotic and some postzygotic barriers affecting gene flow between the edaphically divergent taxa, other mechanisms can also provide effective barriers to reproduction between such taxa. Perhaps a fascinating example yet to be demonstrated lies in the species pair of Layia glandulosa and its derived serpentinite endemic, $L$. discoidea (Gottlieb et al., 1985; Gottlieb and Ford, 1987; Ford and Gottlieb, 1989, 1990). Complete fertility exists between artificial crosses of these two species, but natural hybrids are not found in nature. This suggests that partially or completely reduced hybrid fitness in one or both parental habitats may be responsible for the diversification in this group. Ecological and genetic studies are now under way to explore the role of serpentinite tolerance in the diversification of this species pair (Rajakaruna, Baldwin, and Gottlieb, in progress).

Edaphically restricted species provide fascinating examples for the study of plant speciation. The study of factors contributing to the evolution of edaphically endemic species can shed light on the relationship between adaptation and reproductive isolation. Although speciation is not a uniform process that always follows the same steps, the case studies provided above show that either directly or indirectly adaptation to a specific soil condition can lead to diversification within taxa. Further, studies of multiple or repeated origins of serpentinite tolerance (Raven and Axelrod, 1978; Kruckeberg, 1986, 1991; Mayer et al., 1994; Mayer and Soltis, 1994; Patterson and Givnish, 2002, 2004) or tolerance to other edaphic extremes (Gregory and Bradshaw, 1965; McNeilly and Bradshaw, 1968; Rajakaruna et al., 2003a) suggest that tolerance may come about with relative ease due to changes in only a few loci.

With the advent of novel genetic approaches such as the study of quantitative trait loci (QTLs), it is possible to identify and characterize such loci or even candidate "speciation genes." Perhaps the best-known example in this regard comes from studies done on pollinator-mediated selection. In the genus Mimulus (Bradshaw et al., 1998), QTLs for floral traits associated with pollinator preference and reproductive isolation have been characterized, suggesting that loci of large effect can contribute to speciation. In Aquilegia (Ranunculaceae), a similar association between genes for pollinator preference and reproductive isolation has been recently estab- lished (Hodges et al., 2002). It is evident that traits for pollinator preference are often closely associated, indicating that either pleiotropy or linkage causes some of this integration. In both these QTL studies, reproductive isolation is a by-product of adaptation to pollinators, thus providing a genetic link between adaptation and speciation.

Similarly, in the case studies dealing with edaphically mediated selection one could find comparable associations. In fact, the genetic basis for many of the traits discussed above-salt tolerance (Hurkman, 1992; Taeb et al., 1992; Quesada et al., 2002), drought tolerance (Teulat et al., 1997; Haake et al., 2002; Hsieh et al., 2002), copper tolerance (Macnair, 1983; Fogel et al., 1988), and flowering-time differences (Law and Worland, 1997; McKay et al., 2003) - have already been investigated in wild or model plant species such as Arabidopsis thaliana and cereal crops or in yeast, and it will only be a matter of time before investigators apply this knowledge to their research species. Further, the genetic architecture of serpentinite tolerance is now being investigated by several groups (Bradshaw, Schemske, and colleagues; Bratteler et al., 2002) and will no doubt soon provide a much persuasive picture of the role of the edaphic factor in the diversification of plant lineages.

\section{Acknowledgments}

I thank to Natural Sciences and Engineering Research Council (NSERC) Canada and my postdoctoral supervisor, David Ackerly, for financial support during the current post-doctoral tenure at Stanford University. I also wish to thank Drs. David Ackerly, Susan Harrison, and Jeannette Whitton for useful comments on the manuscript.

\section{REFERENCES}

Al-Hiyaly, S. E. K., McNeilly, T., Bradshaw, A. D., and Mortimer, A. M., 1993, Effect of zinc contamination from electricity pylons. Genetic constraints on selection for zinc tolerance: Heredity, v. 70, p. 22-32.

Allen, W. R., and Sheppard, P. M., 1971, Copper tolerance in some Californian populations of the monkeyflower Mimulus guttatus: Proceedings of the Royal Society of London, B, v. 177, p. 177-196.

Antonovics, J., 1968, Evolution of closely adjacent plant populations. V. Evolution of self fertility: Heredity, v. 23, p. 219-238. 
Antonovics, J., and Bradshaw, A. D., 1970, Evolution in closely adjacent plant populations. viii. Clinal patterns at a mine boundary: Heredity, v. 25, p. 349-362.

Antonovics, J., Bradshaw, A. D., and Turner, R. G., 1971, Heavy metal tolerance in plants: Advances in Ecological Research, v. 7, p. 1-85.

Baskin, J. M., and Baskin, C. C., 1988, Endemism in rock outcrop communities of unglaciated eastern United States: An evaluation of the roles of the edaphic, genetic and light factors: Journal of Biogeography, v. 15, p. 829-840.

Bradshaw, A. D., and McNeilly, T., 1981, Evolution and pollution: London, UK, Edward Arnold Ltd., Studies in Biology no. 130,76 p.

Bradshaw, A. D., McNeilly, T., and Putwain, P. D., 1990, The essential qualities, in Shaw, J., ed., Heavy metal tolerance in plants: Evolutionary aspects: Boca Raton, FL and Los Angeles, CA, CRC Press, p. 323-334.

Bradshaw, H. D., Otto, K. G., Frewen, B. E., McKay, J. K., and Schemske, D. W., 1998, Quantitative trait loci affecting differences in floral morphology between two species of monkeyflower (Mimulus): Genetics, v. 149, p. 367-382.

Bratteler, M., Widmer, A., Baltisberger, M., and Edwards, P. J., 2002, Genetic architecture of traits associated with habitat adaptation in Silene vulgaris (Caryophyllaceae): Bulletin of the Geobotanical Institute ETH, v. 68, p. 95-103.

Cain, S. A., 1944, Foundations of plant geography: New York, NY, Harper Bros.

Chan, R., Baldwin, B. G., and Ornduff, R., 2001, Goldfields revisited: A molecular phylogenetic perspective on the evolution of Lasthenia (Compositae: Heliantheae sensu lato): International Journal of Plant Sciences, v. 162, p. 1347-1360.

,2002, Cryptic Goldfields: A molecular phylogenetic re-investigation of Lasthenia californica sensu lato and close relatives (Compositae: Heliantheae sensu lato): American Journal of Botany, v. 89, p. 1103-1112.

Christie, P., and Macnair, M. R., 1984, Complimentary lethal factors in two North American populations of the yellow monkey flower: Journal of Heredity, v. 75, p. 510-511.

, 1987, The distribution of postmating reproductive isolating genes in populations of the yellow monkeyflower, Mimulus guttatus: Evolution, v. 41, p. 571578.

Crawford, D. J., Ornduff, R., and Vasey, M. C., 1985, Allozyme variation within and between Lasthenia minor and its derivative species, L. maritima (Asteraceae): American Journal of Botany, v. 72, p. 11771184.

Flowers, T. J., Hajibagheri, M. A., and Clipson, N. J. W., 1986, Halophytes: The Quarterly Review of Biology, v. 61, p. 313-337.
Fogel, S., Welch, J. W., and Maloney, D. H., 1988, The molecular genetics of copper resistance in Saccharomyces cerevisiae-A paradigm for non conventional yeasts: Journal of Basic Microbiology, v. 28, p. 147 160.

Ford, V. S., and Gottlieb, L. D., 1989, Morphological evolution in Layia: Character recombination in hybrids between $L$. discoidea and L. glandulosa: Systematic Botany, v. 14, p. 284-296.

, 1990, Genetic studies of floral evolution in Layia. Heredity, v. 64, p. 29-44.

Gardner, M., and Macnair, M. R., 2000, Factors affecting the co-existence of the serpentine endemic Mimulus nudatus Curran and its presumed progenitor Mimulus guttatus Fischer ex DC: Biological Journal of the Linnean Society, v. 69, p. 443-459.

Gillham, M. E., 1956, Ecology of Pembrokeshire islands. V. Manuring by the colonial seabirds and mammals, with a note on seed distribution by gulls: Journal of Ecology, v. 44, p. 429-454.

Gottlieb, L. D., and Ford, V. S., 1987, Genetic and developmental studies of the absence of ray florets in Layia discoidea, in Thomas, H., and Grierson, D., eds., Developmental mutants in higher plants: Cambridge, UK, Cambridge University Press, Society for Experimental Biology Seminar Series, v. 32, p. 1-17.

Gottlieb, L. D., Warwick, S. I., and Ford, V. S., 1985, Morphological and electrophoretic divergence between Layia discoidea and L. glandulosa: Systematic Botany, v. 10, p. 484-495.

Gregory, R. P. G., and Bradshaw, A. D., 1965, Heavy metal tolerance in populations of Agrostis tenuis Sibth. And other grasses: New Phytologist, v. 64, p. 131-143.

Haake, V., Cook, D., Riechmann, J. L., Pineda, O., Thomashow, M. F., and Zhang, J. Z., 2002, Transcription factor CBF4 is a regulator of drought adaptation in Arabidopsis: Plant Physiology, v. 130, p. 639-648.

Hodges, S. A., Whittal, J. B., Fulton, M., and Yang, J. Y., 2002, Genetics of floral traits influencing reproductive isolation between Aquilegia formosa and Aquilegia pubescens: American Naturalist, v. 159, p. S51-S60.

Holland, R. F., and Jain, S. K., 1977, Vernal pools, in Barbour, M. G., and Major, J., eds. Terrestrial vegetation of California: New York, NY, Wiley-Interscience, p. 515533.

, 1981, Insular biogeography of vernal pools in the central valley of California: American Naturalist, v. 117, p. 24-37.

Hsieh, T.-H., Lee, J.-T., Charng, Y.-Y., and Chan, M.-T., 2002, Tomato plants ecotypically expressing Arabidopsis $\mathrm{CBF} 1$ show enhanced resistance to water deficit stress: Plant Physiology, v. 130, p. 618-626.

Hurkman, W. J., 1992, Effect of salt stress on plant gene expression: A review: Plant and Soil, v. 146, p. 145151. 
Jenny, H., 1941, Factors of soil formation, a system of quantitative pedology: New York, NY, McGraw Hill, $281 \mathrm{p}$.

Kruckeberg, A. R., 1984, California serpentines: Flora, vegetation, geology, soils, and management problems: Berkeley, CA, University of California Press, 180 p. , 1986, An essay: The stimulus of unusual geologies for plant speciation: Systematic Botany, v. 11, p. 455-463.

1991, An essay: Geoedaphics and island biogeography for vascular plants: Aliso, v. 13, p. 225-238.

Kruckeberg, A. R., and Rabinowitz, D., 1985, Biological aspects of endemism in higher plants: Annual Review of Ecology and Systematics, v. 16, p. 447-479.

Law, C. N., and Worland, A. J., 1997, Genetic analysis of some flowering time and adaptive traits in wheat: New Phytologist, v. 137, p. 19-28.

Lewis, H., 1962, Catastrophic selection as a factor in speciation: Evolution., v. 16, p. 257-271.

Linhart, Y. B., and Grant, M. C., 1996, Evolutionary significance of local genetic differentiation in plants: Annual Review of Ecology and Systematics, v. 27, p. 237-277.

Liu, E. H., and Godt, M. W., 1983, The differentiation of populations over short distance, in Schonewald-Cox, C. M., Chambers, S. M., MacBryde, B., and Thomas, L., eds. Genetics and Conservation: Menlo Park, CA, Benjamin/Cummings Publ Co., p. 78-95.

Lloyd, R. M., and Mitchell, R. S., 1973, A flora of the White Mountains, California and Nevada: Berkeley, CA, University of California Press.

Macnair, M. R., 1983, The genetic control of copper tolerance in the yellow monkey flower, Mimulus guttatus: Heredity, v. 50, p. 283-293.

Macnair, M. R., and Baker, A. J. M., 1994, Metal tolerance in plants: Evolutionary aspects, in Farago, M. E., ed., Plants and the chemical elements: New York, NY, VCH Publishers, p. 67-86.

Macnair, M. R., and Christie, P., 1983, Reproductive isolation as a pleiotropic effect of copper tolerance in Mimulus guttatus ?: Heredity, v. 50, p. 295-302.

Macnair, M. R, Macnair, V. E., and Martin, B. E., 1989, Adaptive speciation in Mimulus: An ecological comparison of $M$. cupriphilus with its progenitor, M. guttatus: New Phytologist, v. 112, p. 269-279.

Macnair, M. R., and Gardner, M., 1998, The evolution of edaphic endemics, in Howard, D. J., and Berlocher, S. H., eds. Endless forms: Species and speciation: New York, NY, Oxford University Press, p. 157-171.

Mason, H., 1946a, The edaphic factor in narrow endemism. The nature of environmental influences: Madroño, v. 8, p. 209-226.

1946b, The geographic occurrence of plants in highly restricted patterns of distribution: Madroño, v. 8, p. 241-257.

Mayer, M. S., and Soltis, P. S., 1994, The evolution of serpentine endemics: A chloroplast DNA phylogeny of the Streptanthus glandulosus complex (Cruciferae): Systematic Botany, v. 19, p. 557-574.

Mayer, M. S., Soltis, P. S., and Soltis, D. E., 1994, The evolution of Streptanthus glandulosus complex (Cruciferae): Genetic divergence and gene flow in serpentine endemics: American Journal of Botany, v. 81, p. 1288-1299.

McKay, J. K., Richards, J. H., and Mitchell-Olds, T., 2003, Genetics of drought adaptation in Arabidopsis thaliana: I. Pleiotropy contributes to genetic correlations among ecological traits: Molecular Ecology, v. 12, p. 1137-1151.

McNeilly, T., 1968, Evolution in closely adjacent plant populations. III. Agrostis tenuis on a small copper mine: Heredity, v. 23, p. 99-108.

McNeilly, T., and Antonovics, J., 1968, Evolution of closely adjacent plant populations. IV. Barriers to gene flow: Heredity, v. 23, p. 205-218.

McNeilly, T., and Bradshaw, A. D., 1968, evolutionary processes in populations of copper tolerant Agrostis tenuis Sibth.: Evolution, v. 22, p. 108-118.

Mooney, H. A., 1966, Influence of soil type on the distribution of two closely related species of Erigeron: Ecology, v. 47, p. 950-958.

Ornduff, R., 1965, Ornithocoprophilous endemism in pacific basin angiosperms: Ecology, v. 46, p. 864-867.

1966, A biosystematic survey of the Goldfield genus Lasthenia (Compositae: Helenieae): University of California Publications in Botany, v. 40, p. 1-92.

, 1986, Islands on islands: Plant life on the granite outcrops of Western Australia. Harold L. Lyon Arboretum Lecture Number Fifteen: Honolulu, HI, University of Hawaii Press, 28 p.

Patterson, T. B., and Givnish, T. J., 2002, Phylogeny, concerted convergence, and phylogenetic niche conservatism in the core Liliales: Insights from $r b c L$ and $n d h F$ sequence data: Evolution, v. 56, p. 233-252.

, 2004, Geographic cohesion, chromosomal evolution, parallel adaptive radiations, and consequent floral adaptations in Calochortus (Calochortaceae): Evidence from a cpDNA phylogeny: New Phytologist, v. 161, p. 253-264.

Proctor, J., and Woodell, S. R. J., 1975, The ecology of serpentine soils: Advances in Ecological Research, v. 9, p. 255-366.

Quarterman, E., Burbanck, M. P., and Fralish, J. S., 1993, Rock outcrop communities: Limestone, sandstone, and granite, in Martin, W. H., Boyce, S. G., and Echternacht, A. C., eds., Biodiversity of the Southeastern United States, upland terrestrial communities, v. 2: New York, NY, John Wiley and Sons, p. 35-86.

Quesada, V., Garcia-Martinez, S., Piqueras, P., Ponce, M. R., and Micol, J. L., 2002, Genetic architecture of $\mathrm{NaCl}$ tolerance in Arabidopsis: Plant Physiology, v. 130, p. 951-963. 
Rajakaruna, N., 2003, Edaphic differentiation in Lasthenia: A model for studies in evolutionary ecology: Madroño, v. 50, p. 34-40.

Rajakaruna, N., Baldwin, B. G., Chan, R., Desrochers, A. M., Bohm, B. A., and Whitton, J., 2003a, Edaphic races and phylogenetic taxa in the Lasthenia californica complex (Asteraceae: Heliantheae): An hypothesis of parallel evolution: Molecular Ecology, v. 12, p. 1675-1679.

Rajakaruna, N., and Bohm, B. A., 1999, The edaphic factor and patterns of variation in Lasthenia californica (Asteraceae): American Journal of Botany, v. 86, p. 1576-1596.

Rajakaruna, N., Bradfield, G. E., Bohm, B. A., and Whitton, J., 2003b, Adaptive differentiation in response to water stress by edaphic races of Lasthenia californica (Asteraceae): International Journal of Plant Sciences,v. 164, p. 371-376.

Rajakaruna, N., Siddiqi, M. Y., Whitton, J., Bohm, B. A., and Glass, A. D. M., 2003c, Differential responses to $\mathrm{Na}^{+} / \mathrm{K}^{+}$and $\mathrm{Ca}^{2+} / \mathrm{Mg}^{2+}$ in two edaphic races of the Lasthenia californica complex (Asteraceae): A case for parallel evolution of physiological traits: New Phytologist, v. 157, p. 93-103.

Rajakaruna, N., and Whitton, J., 2004, Trends in the evolution of edaphic specialists with an example of parallel evolution in the Lasthenia californica complex, in Cronk, Q. C. B., Taylor, I. E. P., Ree, R., and Whitton, J., eds., Plant adaptation: Molecular biology and ecology, in press.

Raven, P. H., 1964, Catastrophic selection and edaphic endemism: Evolution, v. 18, p. 336-338.

Raven, P. H., and Axelrod, D. I., 1978, Origin and relationships of the Californian flora: University of California Publications in Botany, v. 72, p. 1-134.

Searcy, K. B., and Macnair, M. R., 1990, Differential seed production in Mimulus guttatus in response to increasing concentrations of copper in the pistil by pollen from copper tolerant and sensitive sources: Evolution, v. 44, p. 1424-1435.

Shaw, J., ed., 1990, Heavy metal tolerance in plants: Evolutionary aspects: Boca Raton, FL and Los Angeles, CA, CRC Press, 355 p.

Stam, P., 1983, The evolution of reproductive isolation in closely adjacent plant populations through differential flowering time: Heredity, v. 50, p. 105-118.
Stebbins, G. L., 1942, The genetic approach to problems of rare and endemic species: Madroño, v. 6, p. 241272.

, 1980, Rarity of plant species: A synthetic viewpoint: Rhodora, v. 82, p. 77-86.

Stebbins, G. L., and Major, J., 1965, Endemism and speciation in the California flora: Ecological Monographs, v. 35 , p. 1-35.

Taeb, M., Koebner, R. M. D., Forster, B. P., and Law, C. N., 1992, Association between genes controlling flowering time and shoot sodium accumulation in the Triticeae: Plant and Soil, v. 146, p. 117-121.

Teulat, B., Monneveux, P., Wery, J., Borries, C., Souyris, I., Charrier, A., and This, D., 1997, Relationships between relative water content and growth parameters under water stress in barley: A QTL study: New Phytologist, v. 137, p. 99-107.

Turner, B. L., 1973, Machaeranthera restiformis (Asteraceae): A bizarre new gypsophile from north central Mexico: American Journal of Botany, v. 60, p. 836838.

Turner, B. L., and Powell, A. M., 1979, Deserts, gypsum, and endemism, in J. R. Goodin and D. K. Northington, eds., Arid land plant resources: Proceedings of the International Arid Lands Conference on Plant Resources: Lubbock, TX: International Center for Arid and Semi-Arid Land Studies, Texas Tech University, 96-116.

Vasey, M. C., 1985, The specific status of Lasthenia maritima (Asteraceae), an endemic of seabird breeding habitats: Madroño, v. 32, p. 131-142.

Vickery, R. K., Jr., 1959, Barriers to gene exchange within Mimulus guttatus (Scrophulariaceae): Evolution, v. 13, p. $300-310$.

, 1978, Case studies in the evolution of species complexes in Mimulus: Evolutionary Biology, v. 11, p. 405-507.

Wallace, D. R., 1983, The Klamath Knot: Explorations of myth and evolution: San Francisco, CA, Sierra Club Books, 149 p.

Wyatt, R., and Fowler, N., 1977, The vascular flora and vegetation of North Carolina granite outcrops: Bulletin of the Torrey Botanical Club, v. 104, p. 245-253. 